Available Online : https://proceeding.researchsynergypress.com/index.php/cset/index

RSF Conference Series: Engineering and Technology

ISSN 2809-6843 (Online) | 2809-6878 (Print)

Volume 1 Number 1 (2021): 23-29

\title{
Application of Foliar Fertilizer and Planting Media on Cattleya sp. Orchid Growth
}

\author{
Heti Herastuti ${ }^{1}$, Siwi Hardiastuti Endang Kawuryan ${ }^{2}$ \\ 1, 2 Agrotechnology, Agriculture Faculty UPN "Veteran" Yogyakarta, Indonesia
}

\begin{abstract}
Cattleya is one of the orchid genera, it has many fans. Labellum is large and strike colors. Intergeneric crosses have been made to produce soft colored flower, such as white, pink, red, yellow and brown. Cattleya orchids are known to have large flowers, and they are commonly referred to as The Queen of Orchid. These species are cultivated by several botanists as cut flower commodities. The price of cattleya is costly, so it becomes a business opportunity that needs to be developed. This study aims to examine the types of foliar fertilizers and planting media used on the growth of cattleya orchids. It was conducted between May and August 2021 in the experimental garden of the Faculty of Agriculture, UPN Veteran Yogyakarta using a Split Plot Design with factorial. The first factor, which is foliar fertilizer, consists of quick grow, $\mathrm{AB}$ mix, and focus grow. The second factor of planting media includes fern roots, black moss, and kadaka roots media. The result showed that $\mathrm{AB}$ Mix on fern and kadaka media produced similar plant height compared to other treatments. While on kadaka media, it produced the best leaf length and width, as well as shoot length. Furthermore, the shoot emergence and the number of roots did not show a significant difference. The plants that received quick grow treatment on kadaka and black moss media had similar growth. The number of roots provided the best growth of kadaka and ferns. Further study should be conducted to test AB Mix with various concentrations and planting media.
\end{abstract}

Keywords: Foliar fertilizer, Cattleya sp., planting media

\section{INTRODUCTION}

This is an open access article under the CC-BY-NC license

The cattleya orchid is known as the Queen of Orchids, because of the beauty of its flower shape. Morphologically, the size is larger than other types of orchids, and the flowers consist of petals, column, sepals, and labellum which are combined into a single flower. This plant is of the sympodial type with the characteristics of not having a main stem. Furthermore, the flowers are produced during the growth of new saplings or shoots from the end of the stem.

Cattleya is named after an orchid grower, William Cattley. Initially, William Cattley received a shipment of an unknown plant from William Jackson Hooker, a professor of botany at the University of Glasgow. The plants were obtained from William Swaison who had collected plants from Brasilia in the period 1816-1818. William Cattley employed John Lindley to create plant illustrations and descriptions, and one of the honors, the new genus of orchids was named Cattleya (Widiastoety, 2005).

Cattleya orchids have fragrant flowers in a variety of shapes and color combinations. Many species bloom quite large and stretch for a few centimeters, others bloom smaller but no less beautiful. It flowers once a year depending on the species; however, some hybrids have been cultivated to bloom more than once. It grows naturally attached to other plants such as tree branches, and the leaves are usually dull green. It grows from pseudo bulbs, which store nutrients and water, and it is a long-lived plant that takes four to seven years to mature. The best time to plant these orchids is as soon as new growth appears after they have finished flowering.

The application of foliar is a widespread practice since orchids cannot absorb significant nutrients due to its (Monda et al., 2014) slow growth rate. Therefore, an appropriate fertilization strategy is needed to have a significant impact on their growth rate. Fertilizers are used to promote growth which contains the nutrients needed for orchids. 
The growth and development of orchid seedlings can be spurred by containing micro and macro nutrients (Suradinata et. al., 2012). Fertilization can be done through the roots and leaves. Leaf fertilizer is a compound fertilizer to spur vegetative growth. Foliar fertilizer is applied by spraying all parts of the plant. Absorption of nutrients through foliar fertilizer is more effective than is root fertilizer. Foliar fertilizer is applicate into solid which can be absorbed by plant organism. The foliar fertilizer is needed for the early vegetative growth period is $\mathrm{N}-\mathrm{P}-\mathrm{K}$ with a higher nitrogen $(\mathrm{N})$ composition than is other elements (Hastuti et al., 2016).

According Iswanto (2010), fertilization for orchid plants is applied through roots or leaves, but administration through leaves can suppress $90 \%$ of the way through the roots since only $10 \%$ can be absorbed by plants. Quick grow, $\mathrm{AB}$ mix and focus grow are the type of fertilizers commonly used. Quick grow contains BAP, N 40\%, P 28\%, K 30\%, vitamins B1, B, Cu, Mn, Zn, Fe, and Mo hormones. AB Mix contains $\mathrm{N}, \mathrm{P}, \mathrm{K}, \mathrm{Ca}, \mathrm{Mg}, \mathrm{S}, \mathrm{Fe}, \mathrm{Zn}, \mathrm{Cu}, \mathrm{Mn}, \mathrm{B}, \mathrm{Na}$, and Mo. Meanwhile, focus grow contains $\mathrm{N}, \mathrm{P}, \mathrm{K}, \mathrm{Ca}, \mathrm{Cu}, \mathrm{Fe}$, $\mathrm{Mn}, \mathrm{Mo}$, and $\mathrm{Zn}$. The three types of fertilizers can be applied at a dose of $2 \mathrm{ml} / \mathrm{l}$.

To ensure initial growth conditions, selection of suitable media with high aeration, permeability, and suitable acid is necessary. It maintains long-term conditions without compromising quality to avoid compaction as well as lack of aeration and permeability. Planting media enable plants to grow well under controlled environmental conditions, and it can be solid or porous materials, synthetic or natural, combined or not. The media used include fern roots, kadaka roots, and black moss (Kartana, 2017). Each of the media has a difference in the storage of water necessary for plants.

Using plant media which has high porosity spurs root growth, and however media risks less water. Media which has high porosity can inhibit root growth. Although water holding power better than does light media (Ari et.al., 2016). According Tini et.al. (2019), the result of research showed kadaka root can increase leaf area $19,2 \%$ is compared to fern root and $26,67 \%$ is compared to cocopeat.

\section{LITERATURE REVIEW}

Cattleya has distinctive characteristics that set it apart from other genera, and the size varies from $3 \mathrm{~cm}$ to $23 \mathrm{~cm}$ with 1 to more than 8 flowers per pseudo bulb. The labellum or flower lips are wide and large and have very attractive colors. Furthermore, the Cattleya is a genus of the family Orchidaceae with subfamily Epidendroideae and subtribeLaeliinae. It produces rhizomes that develop into stems with roots, leaves, and flowers (Pant et al., 2021). It is a very tolerant orchid compared to other species, very sturdy, and can withstand fluctuations in temperature, humidity, and drought conditions. The required temperature is between $70^{\circ} \mathrm{F}$ to $80^{\circ} \mathrm{F}\left(21.1^{\circ} \mathrm{C}\right.$ to $\left.26.6^{\circ} \mathrm{C}\right)$ in the daytime and between $55^{\circ} \mathrm{F}$ to $60^{\circ} \mathrm{F}\left(12.8^{\circ} \mathrm{C}\right.$ to $15,6^{\circ} \mathrm{C}$ ) at night.

Cattleya is an evergreen plant with fresh leaves that do not fall off very easily. Generally, it has thick leaves and contains a lot of water. The malic acid content of the leaves increases at night, but decreases during the day. Furthermore, the stomata close during the day and open at night to reduce transpiration, and the shape of the leaves is tapered or round and elongated. The leaves are fleshy, light to dark green in color, with a smooth surface and flat edges. It comes out from the tips of the pseudo bulbs, and the leaves can either be single or double.

The double pseudo bulbs are slightly flattened, hard, and fleshy, and the size varies depending on the species. Meanwhile, the young pseudo bulbs are protected or wrapped by leaves which will dry up after the plants mature. At the base, there is a rhizome root connecting one to another pseudo bulb, which flowers once. cattleya forms new saplings at the base of the pseudo bulb to produce flowers, and it serves as a storage place for food and water. 
Orchid roots are cylindrical, fleshy, soft, easily broken with a tapered, slippery, and slightly sticky end. In dry conditions, it appears silvery-white on the outside and the tips are green or purplish. The roots have a velamen consisting of several layers of cells that are hollow and transparent serving as the protective layer in the root canal system. Furthermore, velamen protects roots from water loss in the process of transpiration and evaporation. Water or nutrients that directly hit the roots will be absorbed by the velamen and the root tips will then be channeled into the plant tissue.

Fertilization application can be conducted indirectly through soil or media, and directly through all parts of the plant above the soil surface, especially the leaves. It is administered in the form of a solution with a low concentration. The fertilizers given to cattleya orchids are Quick grow, AB Mix, and Focus grow. The application can be performed by spraying in the afternoon because the orchid belongs to the CAM class (Crasulace acid metabolism) since the stomata open at night and close during the day Salisbury dan Ross, 1992) CAM plants photosynthesize without losing large amounts of water due to stomata transpiration since it is drought resistant.

Quick grow is a liquid fertilizer for spuring growth plant. Quick grow research has been done by Herlina et.al. (2017), on dendrobium orchid. Dose $2 \mathrm{ml} / \mathrm{l}$ provided height plant and the longest length leaf. According to Herlina et. al. (2017), quick grow increases plant height and leaf length in dendrobium orchids. Focus grow has never been done the research, but can spur shout grow because it contains N, $\mathrm{P}$, K and other nutrients. AB mix increases plant height and total dry weight in pak choy (Bahzar and Santosa, 2018). Several hydroponic entrepreneurs have made nutrient contains can be made according to the plant needs, but however AB Mix has never been tried for orchid.

A good planting media for cattleya orchids have to meet many requirements of not rapidly decaying and decomposing, not being a source of disease for plants, having good aeration and drainage. Furthermore, they should be able to optimally bind water and nutrients, retain moisture around the roots, have a pH of $5-6$, be environmentally friendly, easy to obtain, and relatively cheap. The use of fern root media is difficult due to water binding capacity, aeration ability, and good drainage. Meanwhile, Kadaka root is a part of the fern family, and the shape is like grass and grows attached to the trunks of large trees in forests. It is used as a planting media for epiphytic and terrestrial orchids and has plant tissue, which contains nutrients. This plant can regulate humidity since it is not easy to cause root rot in orchids. Furthermore, the media is durable and can be used for one year. Black Moss can bind water very quickly and store it for a long time.

According to Tini et. al., (2019), kadaka roots can replace the role of ferns and coconut husks, by increasing leaf area and stem diameter. Fern root media can produce good vegetative growth of dendrobium orchids. Fern root has advantages; it is not easy weathered, so that plant can absorb the nutrients. Fern root media contains sugar compounds, amino acids, aliphatic acids, and esters (Andalasari, et. al. 2014). Based on the explanation above, this study aims to examine the types of foliar fertilizers and orchid planting media on the growth of the Cattleya sp.

\section{RESEARCH METHOD}

The study was carried out from May to August 2021 at the Experimental Garden of the Faculty of Agriculture, UPN Veteran Yogyakarta. The orchid seeds used were cattleya from the community pot with equipment of plastic pot, pipette, hand sprayer, ruler. Furthermore, the materials used were cattleya orchid seeds, Quick grow, AB Mix and Focus Grow foliar fertilizer, fern and kadaka roots, black moss, as well as fungicide dithane $\mathrm{M}-45$.

A two-factor split-plot design was used with 3 replications. The first factor was the type of foliar fertilizer consisting of quick grow, AB Mix, and Focus grow. The second was the type of planting media consisting 
of fern roots, kadaka roots, and black moss. Each treatment combination consists of 6 pots so the total pot is 162 pots. The media were immersed in water mixed with dithane M45 for 24 hours and were ready to be used after the wind drought. Furthermore, the planting was conducted using a transparent pot measuring $7 \mathrm{~cm}$ inserted with the media. A week after planting, quick grow, $\mathrm{AB} \mathrm{Mix}$, and Focus grow were sprayed with a concentration of $2 \mathrm{ml} / \mathrm{l}$ every week 2 times for 3 months.

The data were collected by direct observation and measurement in the field, and the plant height, leaf length and width, shoot emergence and length, the number of shoots, root length, and the number of roots were observed. In addition, data were analyzed with a $5 \%$ variance, and when there is a significant difference, Duncan's Multiple Range Test \% will be further used.

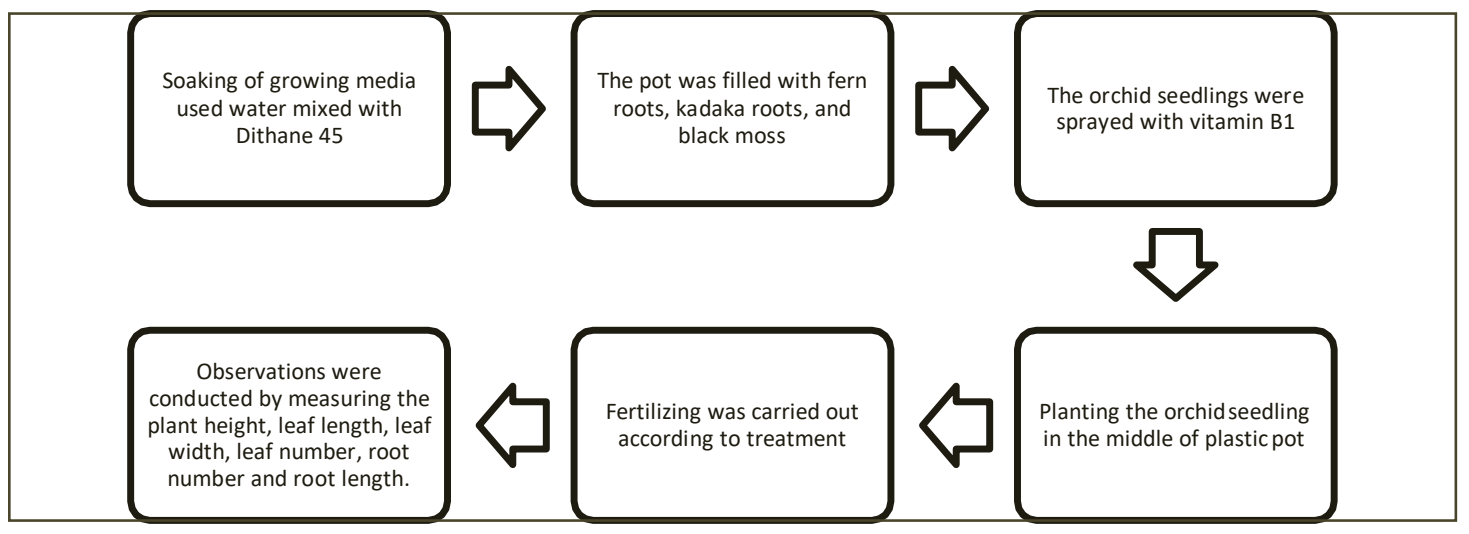

Fig 1. The research process

\section{FINDING AND DISCUSSION}

The results of variance showed that there was an interaction in the increase in plant height, leaf length and width, shoot, and root length in the treatment of foliar fertilizer application and planting media on the growth of cattleya orchids. On the day of shoot emergence, the numbers were not significantly different. Meanwhile, on the number of roots, the type of fertilizer was significantly different.

Table 1 showed that the treatment of AB mix fertilizer on fern root and kadaka root media produced no different plant height but fern root and kadaka root are better than quick grow on fens root, $A B$ Mix on black moss, focus grow on fern root, kadaka root, and black moss. Similarly, quick grow on kadaka root and black moss also produced similar results, and the provision of $\mathrm{AB}$ Mix with $\mathrm{N}, \mathrm{P}, \mathrm{K}, \mathrm{Ca}, \mathrm{Mg}, \mathrm{S}, \mathrm{Fe}, \mathrm{Zn}$, $\mathrm{Cu}, \mathrm{Mn}, \mathrm{B}, \mathrm{Na}$, and Mo contents on ferns root and kadaka root media stimulates plant growth. $\mathrm{N}$ is needed to stimulate the vegetative growth of plants. Pramitasari et.al., (2016) also stated that nitrogen is a constituent of amino acids, chlorophyll, and other compounds in metabolic processes.

The results of photosynthesis are used for the growth of plant seed organs (Hastuti et. al, 2016). Fern root and kadaka root planting media have the opportunity to store greater water. Aritonang and Surtinah (2016) explained that water and nutrients availability activate the process of cell division and enlargement. In addition, adequate nutrients are needed by the cell organelles to produce food for plants.

Table 1. Application of foliar fertilizer and type of planting media on the increase in cattleya plant height ( $\mathrm{mm})$

\begin{tabular}{lcccc}
\hline Treatment & \multicolumn{4}{c}{ Planting Media } \\
\hline Foliar Fertilizer & Fens Root & Kadaka Root & Black Moss & Average \\
\hline Quick grow & $2.83 \mathrm{bc}$ & $3.50 \mathrm{ab}$ & $3.16 \mathrm{ab}$ & 3.16 \\
AB Mix & $3.83 \mathrm{a}$ & $4.16 \mathrm{a}$ & $2.16 \mathrm{~cd}$ & 3.38 \\
Focus grow & $2.00 \mathrm{~d}$ & $2.33 \mathrm{~cd}$ & $2.00 \mathrm{~cd}$ & 2.11 \\
\hline Average & 2.89 & 3.33 & 2.44 & $(+)$ \\
\hline
\end{tabular}


Description: The mean followed by different letters indicates that there is a difference in the Duncan Multiple Range Test with a significant $5 \%$. The data displayed is the original data that has been transformed. The sign $(+)$ indicates there is an interaction.

Table. 2 showed that the combination of AB Mix with kadaka root resulted in the longest leaves compared to other treatments. In Table 3, AB Mix with kadaka roots produced the widest leaves compared to other treatments. This is because it contains nitrogen which is a constituent component of proteins and enzymes as plant essential compounds. Kadaka root media can bind and provide water and nutrients to support the photosynthesis process. Excess kadaka roots can support plant growth because the orchid roots can attach well to the media. According to Dewi (2014), upright plants take advantage of sunlight and the content in the air to metabolism. The photosynthetic yield of such plants is higher than others since it is supported by kadaka roots.

Table 2. Application of foliar fertilizer and type of planting media on the increase in Cattleya leaf length (mm)

\begin{tabular}{lcccc}
\hline Treatment & \multicolumn{4}{c}{ Planting Media } \\
\hline Foliar Fertilizer & Fens Root & Kadaka Root & Black Moss & Average \\
\hline Quick grow & $3.50 \mathrm{~b}$ & $3.50 \mathrm{~b}$ & $1.83 \mathrm{e}$ & 2.94 \\
AB Mix & $3.67 \mathrm{~b}$ & $4.67 \mathrm{a}$ & $1.67 \mathrm{de}$ & 3.34 \\
Focus grow & $1.17 \mathrm{e}$ & $2.50 \mathrm{c}$ & $2.17 \mathrm{~cd}$ & 1.95 \\
\hline Average & 2.78 & 3.56 & 1.83 & $(+)$ \\
\hline
\end{tabular}

Description: The mean followed by different letters indicates that there is a difference in the Duncan Multiple Range Test with a significant $5 \%$. The data displayed is the original data that has been transformed. The sign (+) indicates there is an interaction.

Table 3. Application of foliar fertilizer and type of planting media on the increase in Cattleya leaf width (mm)

\begin{tabular}{lcccc}
\hline Treatment & \multicolumn{4}{c}{ Planting Media } \\
\hline Foliar Fertilizer & Fens Root & Kadaka Root & Black Moss & Average \\
\hline Quick grow & $1.33 \mathrm{bc}$ & $1.50 \mathrm{~b}$ & $1.17 \mathrm{~cd}$ & 1.33 \\
AB Mix & $1.50 \mathrm{~b}$ & $1.83 \mathrm{a}$ & $1.00 \mathrm{~d}$ & 1.43 \\
Focus grow & $1.67 \mathrm{~cd}$ & $1.67 \mathrm{~cd}$ & $1.67 \mathrm{~cd}$ & 1.67 \\
\hline Average & 1.50 & 1.67 & 1.28 & $(+)$ \\
\hline
\end{tabular}

Description: The mean followed by different letters indicates that there is a difference in the Duncan Multiple Range Test with a significant $5 \%$. The data displayed is the original data that has been transformed. The sign (+) indicates there is an interaction.

Table 4. Showed that the day of shoot emergence and the numbers were not significantly different in the treatment of fertilizer types and planting media. Therefore, the emergence of shoots is genetically influenced by the plant. The planting media cannot affect the number of shoots because the growth of orchids is slow. Meanwhile, the number of roots showed differences in growth, and the treatment of kadaka media showed better growth than black moss but not different from fern media. The beneficial nature of fern roots is that they have enough nutrients since the orchid roots grow freely, and they also have air cavities.

Table 4. Application of foliar fertilizer and type of planting media on the Emergence and Number of shoots, as well as the number of roots of cattleya

\begin{tabular}{|c|c|c|c|}
\hline Foliar Fertilizer & The day of shoot emergence & The Number of Shoots & $\begin{array}{c}\text { The Number of } \\
\text { Roots }\end{array}$ \\
\hline Quick grow & $35.67 \mathrm{a}$ & $1.30 \mathrm{a}$ & $2.89 \mathrm{a}$ \\
\hline AB Mix & $37.11 \mathrm{a}$ & $1.33 \mathrm{a}$ & $2.72 \mathrm{a}$ \\
\hline Focus grow & $33.56 \mathrm{a}$ & $1.26 \mathrm{a}$ & $3.00 \mathrm{a}$ \\
\hline
\end{tabular}


RSF Conference Series: Engineering and Technology

Vol. 1 (1), 23-29

Application of Foliar Fertilizer and Planting Media on Cattleya sp. Orchid Growth

Heti Herastuti, Siwi Hardiastuti E. Kawuryan

\begin{tabular}{lccc}
\hline Media Type & & & \\
\hline Fens Root & $34.00 \mathrm{p}$ & $1.32 \mathrm{p}$ & $2.94 \mathrm{ab}$ \\
Kadaka Root & $37.67 \mathrm{p}$ & $1.31 \mathrm{p}$ & $3.17 \mathrm{a}$ \\
Black Moss & $34,67 \mathrm{p}$ & $1,26 \mathrm{p}$ & $2,50 \mathrm{~b}$ \\
\hline Interaction & $(-)$ & $(-)$ & $(-)$
\end{tabular}

Description: The mean followed by different letters indicates that there is a difference in the Duncan Multiple Range Test with a significant $5 \%$. The data displayed is the original data that has been transformed. The sign (+) indicates there is an interaction.

Table 5. Showed that the combination of AB Mix with kadaka roots produced the longest shoot compared to other treatments. This is because it greatly affects the vegetative growth of orchids with its nitrogen nutrients. In addition, $\mathrm{AB}$ Mix includes a compound fertilizer with many components such as $\mathrm{Zn}, \mathrm{Cu}, \mathrm{Mn}$, $\mathrm{B}, \mathrm{Na}$, and Mo to increase the growth of orchids. Kadaka root can store more water. AB Mix also contains N, P, K. Nitrogen is one of macro nutrient. According Pramitasari et. al., (2016), is one of the most important things in chlorophyll. Chlorophyll is one of the main compounds in photosynthesis procces. Giving the high nitrogen, so chlorophyll number will increase. Photosynthate is used for vegetative growth.

Table 5. Application of foliar fertilizer and type of planting media on Cattleya shoot length (mm)

\begin{tabular}{lcccc}
\hline Treatment & \multicolumn{4}{c}{ Planting Media } \\
\hline Foliar Fertilizer & Fens Root & Kadaka Root & Black Moss & Average \\
\hline Quick grow & $5.20 \mathrm{~b}$ & $6.27 \mathrm{~b}$ & $6.73 \mathrm{~b}$ & 6.07 \\
AB Mix & $6.10 \mathrm{~b}$ & $10.17 \mathrm{a}$ & $5,73 \mathrm{~b}$ & 7.33 \\
Focus grow & $5.57 \mathrm{~b}$ & $5.17 \mathrm{~b}$ & $6.67 \mathrm{~b}$ & 5.80 \\
\hline Average & 5.62 & 7.20 & 6.38 & $(+)$ \\
\hline
\end{tabular}

Description: The mean followed by different letters indicates that there is a difference in the Duncan Multiple Range Test with a significant $5 \%$. The data displayed is the original data that has been transformed. The sign (+) indicates there is an interaction.

Table 6. Application of foliar fertilizer and type of planting media on root length (mm)

\begin{tabular}{lcccc}
\hline Treatment & \multicolumn{4}{c}{ Planting Media } \\
\hline Foliar Fertilizer & Fens Root & Kadaka Root & Black Moss & Average \\
\hline Quick grow & $1.52 \mathrm{~d}$ & $3.37 \mathrm{a}$ & $3.67 \mathrm{a}$ & 2.85 \\
AB Mix & $2.40 \mathrm{bc}$ & $4.06 \mathrm{a}$ & $1.73 \mathrm{~d}$ & 2.73 \\
Focus grow & $1.77 \mathrm{~cd}$ & $2.53 \mathrm{~b}$ & $3.23 \mathrm{ab}$ & 2.51 \\
\hline Average & 1.89 & 3.32 & 2.87 & $(+)$ \\
\hline
\end{tabular}

Description: The mean followed by different letters indicates that there is a difference in the Duncan Multiple Range Test with a significant $5 \%$. The data displayed is the original data that has been transformed. The sign (+) indicates there is an interaction.

Table 6. Showed that the combination of Quick grow with kadaka media and black moss was not significantly different from $A B$ Mix on Cattleya root length. $A B$ Mix is a hydroponic fertilizer that can be used for orchids. Quick grow contains BAP, N 40\%, P 28\%, K 30\%, vitamins B1, B, Cu, Mn, Zn, Fe, and Mo. $\mathrm{AB}$ Mix contains $\mathrm{N}, \mathrm{P}, \mathrm{K}, \mathrm{Ca}, \mathrm{Mg}, \mathrm{S}, \mathrm{Fe}, \mathrm{Zn}, \mathrm{Cu}, \mathrm{Mn}, \mathrm{B}, \mathrm{Na}$, and Mo. Nutrient contains in the fertilizer almost the same, so it can spur shoot in kadaka roots and black moss. Quick grow on the kadaka root and black moss also AB Mix on the kadaka root provide a good length root. According Tirta (2006), kadaka root has soft fiber so it can save water and nutrient better than has the other media.

\section{CONCLUSION AND FURTHER RESEARCH}

This research is a field experiment, where foliar fertilizers are quick grow, AB Mix and focus grow, while planting media uses fens root, kadaka root and black moss. Quick grow contains BAP, N 40\%, P 28\%, K $30 \%$, vitamins B1, B, Cu, Mn, Zn, Fe, and Mo hormones. AB Mix contains N, P, K, Ca, Mg, S, Fe, Zn, Cu, Mn, B, $\mathrm{Na}$, and Mo. Meanwhile, focus grow contains $\mathrm{N}, \mathrm{P}, \mathrm{K}, \mathrm{Ca}, \mathrm{Cu}, \mathrm{Fe}, \mathrm{Mn}, \mathrm{Mo}$, and $\mathrm{Zn}$. The three types of fertilizers and growing media ferns root, $\mathrm{Ab}$ Mix and focus grow were tested in this study. 
The findings and discussion showed that $\mathrm{AB}$ Mix on fern and kadaka media produced similar plant height compared to other treatments. While on kadaka media, it produced the best leaf length and width, as well as shoot length. Furthermore, the shoot emergence and the number of roots did not show a significant difference. The plants that received quick grow treatment on kadaka and black moss media had similar growth. The number of roots provided the best growth of kadaka and ferns. Further study should be conducted to test $\mathrm{AB}$ Mix with various concentrations and planting media.

\section{Acknowledgment}

The authors are grateful to the LPPM UPN Veteran Yogyakarta for funding this study through an applied grant.

\section{REFERENCES}

Andalasari, T.D., Yafisham, \& Nuraini. 2014. Response of Dendrobium Orchid Growth to Types of Planting Media and Leaf Fertilizer. Journal of Applied Agricultural Research. 14(3):167-173.

Andriyani, L.Y., Buhaira \& Nancy. (2017). The Effect of Concentration and Frequency of Leaf Fertilizer Spraying on the Growth of Dendrobium Orchid (Dendrobium Jade Gold) Plantlets Acclimatization Stage. Journal of Agronomy 10(1), 51-54

Ari, A.N.H.G., M. Melati, \& S.A. Aziz. 2016. Production of Seedlings Tempuyung (Sonchus arvensis L) with Different Compositions and Volumes of Growing Media. J. Hort. Indonesia. 7(3): 195-203.

Aritonang, S., \&Surtinah, S. 2018. Stimulation of Melon Results (Cucumis melo, L.) using Bioto Grow Gold (BGG). Agricultural Scientific Journal, 15(1): 35-41

Bahzer, M.H. \& Santosa, M. 2018. Effect of Nutrition and Planting Media on The Growth and Yield of Pakcoy Plants (Brassica rapa L. var. chinensis) with Axis Hydroponic System. Jurnal Produksi Tanaman. 6(7) : 1273-1281.

Burhan, B. (2016). Effect of Fertilizer and Concentration Benzyladenine (BA) on The Growth and Flowering of Orchid Hybrid Dendrobium. Journal of Application Agriculture Research 16(33), 194-204.

Dewi, T.A., Yafisham, \& Nuraini. 2014. Response of Dendrobium Orchid Growth to Types of Planting Media and Leaf Fertilizers. Jurnal Penelitian Pertanian Terapan 14(1): 76-82

Febriani, S., Ganefianti, D.W., Romeida, A.\& Herawati, R. (2019). Acclimatization of Pencil Orchid (Papillionanthe hookeriana Rehb.f) as Affected by Different Types of Planting Media and Fertilizing Frequency. Akta Agrosia, 22(1), 36 - 41.

Hastuti, W., Prihastuti, E., Haryanti, S. \& Subagio, A. 2016. Combination of Gandasil D Leaf Fertilizer with Nano-Silicate Fertilizer against Mangrove Seed Growth (Bruguiera gymnorrhiza). Jurnal Biologi, $5(2): 38-48$

Herlina, N., Gesriantuti, N., \& Restiawati, A. 2017Combination of Planting Media and Giving Various Doses of Fertilizer Grow Quick LB to Orchid Growth Dendrobium sp. Post Acclimatization. Jurnal Photon 8(1): 23-32.

Iswanto, H. 2002. Orchid Care Instructions. Agromedia Pustaka. Jakarta.

Kartana, S.N. 2017. test various planting media in increasing the growth of moon orchid seedlings from nature. PIPER Reseach Journal. 24(13): 19-25.

Marlina, G., Marlinda, \& Rosneti, H. (2019). Using of Various Growing Media and Application of Growmore Fertilizer on The Acclimatization of Dendrobium Orchids. Agricultural Scientific Journal, 15(2), 105114.

Monda, T., Dash, p.k., Ahmed., Islam, \& Ali. 2014. Growth performance of orchid (Dendrobium sp.) as influenced by different NPK spray concentration. International Juornal of Biosciences, 4(7): 15-27.

Pramitasari, H.E., Wardiati, T., \& Nawawi, M. 2016. Effect of Nitrogen Fertilizer Dose and Plant Density Level on Your Plant Growth and Yield (Brassica oleraceae L.). Jurnal Produksi Tanaman. 4(1):49-56.

Salisbury, F.B. \& Ross, C.W. (1995). Plant Physiology. CBS Publishers \& Distributors.

Suradinata, Y.R. A. Nurani., \& A. Setiadi. 2012. The Influence of The Combination of Planting Media And The Concentration Of Leaf Fertilizer On The Growth Of The Orchid Dendrobium Sp. Plant. At The Acclimatization Stage. J. Agrivigor. 11(2):104-116.

Tini, E.W., Sulistyanto, P. \& Sumartono, G.H. 2019. Acclimatization Of Orchids (Phalaenopsis Amabilis) With Different Planting Media and The Provision of Leaf Fertilizer. Jurnal Hortikultura Indonesia Vol. 10(2): 119-127.

Tirta, I. G. 2006. Influence of Several Types of Planting Media And Leaf Fertilizers on The Vegetative Growth of Jamrud Orchids (Dendrobium macrophyllum A. Rich) Biodeversitas. 7(1): 81-84.

Widiastoety, D. 2005. Taking care of the cattleya. Penebar Swadaya. Jakarta. 